\title{
Introduction to the Special Issue on Leadership and Culture in the Middle East
}

\author{
Hayat Kabasakal \\ Department of Management, Boğaziçi University, Istanbul, Turkey \\ Ali Dastmalchian* \\ Faculty of Management, University of Lethbridge, Alberta, Canada
}

This Special Issue on "Leadership and Culture in the Middle East" focuses on values and practices as well as effective leadership attributes that are widely shared in Middle Eastern societies. National boundaries are utilised to approximate societal culture and leadership preconceptions. Data collected from four Middle Eastern nations (Iran, Kuwait, Turkey, and Qatar) form the basis of the articles in this Special Issue. Furthermore, at least part of the data collected in these four societies is composed as part of the GLOBE (Global Leadership and Organisational Behaviour Effectiveness) project. A review of the literature shows that there is scarce knowledge on societal and organisational culture and leadership practices in Iran, Kuwait, Turkey, and Qatar. In this respect, this forum would be an important document for providing information on societal and organisational norms and practices, and leadership attributes that are perceived to be effective in this region of the world.

The first paper in this collection, entitled "Project GLOBE: An Introduction", is written by Robert House, Mansour Javidan, and Peter Dorfman. It provides an overview of the GLOBE project, a unique and large scale study of leadership and culture in 61 nations. GLOBE examines the interrelationships among societal culture, organisational culture, and organisational leadership using multiple methodologies. The constructs, objectives and the model utilised in the GLOBE project are described in this manuscript.

Ikhlas A. Abdalla and Moudi A. Al-Hamoud wrote the second paper entitled "Exploring the Implicit Leadership Theory in the Arabian Gulf States". This article on the Arab culture focuses on quantitative and

\footnotetext{
* Address for correspondence: Ali Dastmalchian, Faculty of Management, University of Lethbridge, 4401 University Drive, Lethbridge, Alberta T1K 3M4, Canada. Email: dastmal@uleth.ca 
qualitative findings about effective leader attributes in Kuwait and Qatar based on the data they collected as part of the GLOBE initiative. The authors discuss similarities as well as differences between Kuwait and Qatar in terms of desirable leader attributes. They interpret their findings within the framework of societal and organisational values and management practices in Arab countries.

The third article written by Ali Dastmalchian, Mansour Javidan, and Kamran Alam is entitled "Effective Leadership and Culture in Iran: An Empirical Study". This article focuses on Iranian culture and effective leadership dimensions in the Iranian case. The authors present the findings on aspects of Iranian societal culture using data from 300 Iranian managers. Utilising GLOBE societal culture dimensions, this study reports a comprehensive account of Iranian societal culture and makes comparisons between the Iranian findings and those of other nations. Using the GLOBE leadership instrument, Dastmalchian, Javidan, and Alam develop seven dimensions of effective leadership that reflect the cultural values of Iranian society. They then discuss their findings in terms of universally accepted leadership traits and culture-specific attributes.

The fourth manuscript focuses on societal and organisational culture and effective leadership characteristics in Turkey. Selda Fikret Paşa, Hayat Kabasakal, and Muzaffer Bodur are the authors of this article entitled "Society, Organisations and Leadership in Turkey". It is based on qualitative data collected in Turkey for the GLOBE project and quantitative data that were obtained in an independent research project. The authors analyse the relationship between observed leadership behaviours and organisational culture in Turkish organisations. In addition, they discuss the perceptions of Turkish managers regarding outstanding leader attributes.

Paul Blyton concludes this Special Issue with his article, "The General and the Particular in Cross-National Comparative Research", in which he integrates the findings of the papers and extends the implications of the studies reported here to the broader question of cross-national research.

Defining the country as unit of analysis has important implications for managers and academics. Managers working in multinational corporations can understand the similarities and differences between the parent and host cultures. With this knowledge they can better predict the difficulties in adopting organisational policies and leadership practices. Furthermore, multinational companies can develop training programmes for their expatriates based on this knowledge. Academics can comprehend the limits of generalisability of their findings and theories. In recent years, there has been an upsurge of cross-cultural and comparative management studies in the academic world. These studies portray the necessity of avoiding global generalisations and focusing on local cultures. This issue would contribute to academic studies in terms of highlighting the limits of generalisability of

(C) International Association for Applied Psychology, 2001. 
assumptions regarding cultural norms, practices, and effective leadership characteristics.

While national cultures have their unique attributes, previous work has found that there are also clusters of nations where geographic location serves as the basis of the cluster (Ronen \& Shenkar, 1985). Ronen and Shenkar's review of previous work has portrayed that nine geographic clusters have emerged: Anglo, Germanic, Nordic, Latin European, Latin American, Near East, Far East, Arabic, and Independents. In Ronen and Shenkar's grouping, based on Hofstede's (1980) findings, Iran and Turkey, together with Greece and the former Yugoslavia grouped under the Near East category. Due to small sample sizes obtained from the Arab countries, Hofstede (1983) grouped Egypt, Lebanon, Libya, Kuwait, Iraq, Saudi Arabia, and UAE together as representing the Arab countries.

In an attempt to cluster the countries, Hofstede (1983) formulated the positioning of countries based on three diagrams: (1) power distance $\times$ individualism, (2) power distance $\times$ uncertainty avoidance, and (3) uncertainty avoidance $\times$ masculinity scales. In the power distance $\times$ individualism matrix, Arab countries, Iran, and Turkey positioned in the same cluster, representing large power distance and low individualism cultures. In the power distance $\times$ uncertainty avoidance and uncertainty avoidance $\times$ masculinity matrices, Arab countries and Iran positioned in the same clusters, with Turkey being placed in the neighbouring clusters, while they all placed in the same quadrant. In other words, in addition to their collectivist character, Arab countries, Iran, and Turkey all stood out as large power distance, strong uncertainty avoidance, and masculine societies, thus showing a similarity in terms of these cultural characteristics.

It can be argued that geography precedes some important variables like language, ethnicity, climate, and religion and these variables are considered to have an impact on some culture dimensions. All four societies that are analysed in this Special Issue are predominantly Muslim. Thus, it would be expected that Islam would have an impact on at least some cultural dimensions as well as implicit leadership characteristics that are perceived to be effective.

While a great majority of the population in Iran, Kuwait, Turkey, and Qatar are Muslims, some differences in the role of religion in these societies warrant attention. Turkey stands out as being different from Iran, Kuwait, and Qatar in some respects. Despite the fact that 99 per cent of the Turkish population is Muslim, the Turkish state is secular. The formal state ideology, which is based on principles of Kemalism, is based on the separation of religion and state. In other words, the state is independent of religious rules and is run by secular rules, which are mainly adopted from the West. On the other hand, in Iran, Kuwait, and Qatar, states are not secular but religious laws dominate the running of the states.

(C) International Association for Applied Psychology, 2001. 
Furthermore, there are differences in the Islamic sects that are accepted among these four Middle Eastern nations. Iran is different from the other three nations in that Iranian people predominantly accepted the "Shiite" sect while the Kuwaiti, Turkish, and Qatari people largely belong to the "Sunni" sect.

Although all four nations included in this forum are predominantly Islamic, they speak different languages and have different ethnic backgrounds. While the two Arabic populations, i.e. Kuwait and Qatar, are similar in terms of language and ethnicity, Iranian people predominantly speak Persian and are of Persian origin. The Turkish citizens are predominantly of Turkish origin and the official language is Turkish. Thus, these differences in language and ethnic origins in addition to other socioeconomic and institutional factors may account for part of the differences in the cultural practices of the four nations located in the Middle East region. On the other hand, the Islamic religion seems to be an important common attribute of the societies included in this forum.

Quantitative data based on GLOBE culture dimensions portray the findings for the four nations in terms of societal practices. In all four nations,

TABLE 1

Societal Culture "As Is" Scores of Iran, Kuwait, Turkey, and Inter-country Rankings**

\begin{tabular}{|c|c|c|c|c|c|c|c|}
\hline Societal Culture: "As Is" & Iran & Kuwait & Turkey & Qatar & $\begin{array}{l}\text { Highest } \\
\text { (Country) }\end{array}$ & $\begin{array}{l}\text { Lowest } \\
\text { (Country) }\end{array}$ & $\begin{array}{l}\text { World } \\
\text { Mean }\end{array}$ \\
\hline Uncertainty Avoidance & 3.67 & 4.21 & 3.63 & 3.99 & $\begin{array}{c}5.37 \\
\text { (Switzerland) }\end{array}$ & $\begin{array}{c}2.88 \\
\text { (Russia) }\end{array}$ & 4.16 \\
\hline Power Distance & $5.43^{*}$ & 5.12 & 5.57 & 4.73 & $\begin{array}{c}5.80 \\
\text { (Morocco) }\end{array}$ & $\begin{array}{c}3.89 \\
\text { (Denmark) }\end{array}$ & 5.10 \\
\hline Collectivism I : I-C & 3.88 & 4.49 & 4.03 & 4.50 & $\begin{array}{c}5.22 \\
\text { (Sweden) }\end{array}$ & $\begin{array}{c}3.25 \\
\text { (Greece) }\end{array}$ & 4.23 \\
\hline $\begin{array}{l}\text { Collectivism II : Family } \\
\text { Coll. }\end{array}$ & 6.03 & 5.80 & 5.88 & 4.71 & $\begin{array}{c}6.36 \\
\text { (Philippines) }\end{array}$ & $\begin{array}{c}3.53 \\
\text { (Denmark) }\end{array}$ & 5.08 \\
\hline Gender Egalitarianism & $2.99 *$ & 2.58 & 2.89 & 3.63 & $\begin{array}{c}4.08 \\
\text { (Hungary) }\end{array}$ & $\begin{array}{c}2.50 \\
\text { (South Korea) }\end{array}$ & 3.38 \\
\hline Assertiveness & 4.04 & 3.63 & 4.53 & 4.11 & $\begin{array}{c}4.80 \\
\text { (Albania) }\end{array}$ & $\begin{array}{c}3.38 \\
\text { (Sweden) }\end{array}$ & 4.13 \\
\hline Future Orientation & 3.70 & 3.26 & 3.74 & 3.78 & $\begin{array}{c}5.07 \\
\text { (Singapore) }\end{array}$ & $\begin{array}{c}2.88 \\
\text { (Russia) }\end{array}$ & 3.83 \\
\hline Performance Orientation & 4.58 & 3.95 & 3.83 & 3.45 & $\begin{array}{c}4.94 \\
\text { (Switzerland) }\end{array}$ & $\begin{array}{c}3.20 \\
(\text { Greece })\end{array}$ & 4.07 \\
\hline Humane Orientation & 4.23 & 4.52 & 3.94 & 4.42 & $\begin{array}{c}5.23 \\
\text { (Zambia) }\end{array}$ & $\begin{array}{c}3.18 \\
\text { (Germany- W) }\end{array}$ & 4.07 \\
\hline
\end{tabular}

*Iranian data have fewer scales in these two dimensions than the GLOBE scales.

*** Means range between 1 and 7 , where $1=$ low and $7=$ high.

(C) International Association for Applied Psychology, 2001. 
GLOBE data are collected via self-administered questionnaires filled out by middle level managers. The sample characteristics in the four nations are as follows: in Iran 300 middle managers in financial services, telecommunications, and food processing sectors, in Kuwait 101 middle managers that work in financial services, ministry of transportation and telecommunication sectors, in Turkey 323 middle managers employed in financial services and food processing sectors, and in Qatar 78 middle managers employed in the financial services sector and Ministry of Transportation. Table 1 shows the results of the societal practices, respectively for Iran, Kuwait, Turkey, and Qatar. Societal practices are measured by asking the respondents how the current situation is in their societies ("as is" scores) on a 7-point scale, where $1=$ low and $7=$ high.

An analysis of societal cultural norms ("as is" scores) for Iran, Kuwait, Turkey, and Qatar shows many similarities among these countries. Given the fact that the Iranian data have fewer items in the gender egalitarianism and power distance dimensions than the GLOBE scales, these two dimensions are omitted from comparisons. All four countries seem to be very close to each other in terms of their future-orientation scores. The average of 61 societies for future orientation is 3.83 , while the minimum score is 2.88 (Russia) and the maximum score is 5.07 (Singapore). The future orientation scores for Iran (3.70), Kuwait (3.26), Turkey (3.74), and Qatar (3.78) are all below the world average and are very close to each other.

In addition to the great overlap in the future orientation scores of the four countries, there are similarities in the gender egalitarianism, uncertainty avoidance, power distance, assertiveness, performance orientation, humane orientation, and in-group collectivism scores of the countries in this region of the world. In terms of gender egalitarianism, Iran (2.99), Kuwait (2.58), and Turkey (2.89) have masculine practices, while Qatar (3.63) seems to be on the more feminine side, where the world average is 3.38 , minimum and maximum scores are 2.50 and 4.08 , respectively. Uncertainty avoidance scores for Iran (3.67), Turkey (3.63), and Qatar (3.99) are below the world average (4.16), and Kuwait (4.21) is above the world average (4.16) where the minimum score is 2.88 and the maximum score is 5.37. In terms of the power distance dimension, Iran (5.43), Kuwait (5.12), and Turkey (5.57) seem to have practices that foster unequal distribution of power, while Qatar (4.73) has more egalitarian practices (world mean $=5.10$; $\min .=3.25$; max. $=5.80$ ). For the assertiveness dimension, while Turkey (4.53) scores above the world average (4.13), Iran (3.36), Kuwait (3.63), and Qatar (4.11) carry unassertive qualities $(\min .=3.36$, $\max .=4.80$ ). For performance orientation, only Iran (4.58) seems to be above the world average (4.07), while Kuwait (3.95), Turkey (3.83), and Qatar (3.45) are below the world average $(\min .=3.20$, max. $=4.07)$. For humane orientation, while Turkey (3.94) is below the world average (4.07), Iran (4.23), Kuwait (4.52), and

(C) International Association for Applied Psychology, 2001. 
Qatar (4.42) are above the world average $(\min .=3.18$, $\max .=5.23)$. Finally, in terms of in-group collectivism, Iran (6.03), Kuwait (5.80), and Turkey (5.88) are among the most collectivist societies of the world, while Qatar (4.71) seems to be below the world average (5.08) in terms of this dimension $(\min .=3.18, \max .=6.36)$. The four nations have a more mixed picture in terms of the societal collectivism dimension, where Kuwait (4.49) and Qatar (4.50) have societal practices that tend to encourage and reward collective distribution of resources and collective action, while Iran (3.88) and Turkey (4.03) are more individualistic in this respect (world mean $=4.23$; $\mathrm{min} .=3.25$; $\max .=5.22$ ).

Future orientation as a culture variable in the GLOBE project involves making plans and forecasts and having a long-term perspective in society. All four nations, i.e. Iran, Kuwait, Turkey, and Qatar, are found to be below the world average and are very close to each other. The concept of "fate" in Islam requires special attention as a factor negatively influencing future orientation of societies. Believing in fate and destiny is a strongly rooted cultural aspect in Islamic societies. According to amentu in studies of Islam, believing in fate is among the basic principles of faith in God in the Islamic religion (Ilmihal, 1999). The concept of fate in Islam involves acceptance of all deeds that occurred in the past or that will occur in the future as prearranged and perhaps within God's preordaining. On the other hand, there are many verses in the Koran that explain the importance of a human being's responsibility and choice of his/her actions. Although the concept of fate and its use in the Islamic world is complex and requires more detailed explanation, it does help explain some common cultural attributes in the nations under study. That is, the effect of fate on cultural beliefs demonstrates itself as merely acceptance of all conduct as coming from God and preordained. This deeply rooted belief is manifested in low future orientation in the Islamic countries in the Middle East.

While the concept of fate and the associated low scores in the future orientation dimension is frequently observed at the societal level, organisations might have different practices compared to societies at large. For example, in the third article of this special issue, Passa, Kabasakal, and Bodur found that Turkish respondents mentioned future orientation among the dominant norms and practices that are prevalent in their workplaces, although not as frequently as collectivist or high power distance norms and practices. Furthermore, in another study using the GLOBE data on societal and organisational culture, Kabasakal and Bodur (1998) found Turkish organisations to be significantly more future orientated compared to Turkish society at large. They argued that the necessities of fulfilling the requirements of the task and the higher education levels of the workforce could account for the higher levels of future orientation in organisations compared to society in the Turkish context.

(C) International Association for Applied Psychology, 2001. 
In addition, while societies in the four countries have low future orientations, leaders are expected to exhibit this characteristic to a greater extent. Abdalla and Al-Homoud in their paper on Kuwait and Qatar highlight the same discrepancy and explain that there is a contrast between the relatively low performance orientation and future orientation practices that are dominant in Arab societies and the desirable leadership profile that requires the leader to strongly endorse performance and future orientations. Similarly, leaders are expected to endorse future orientation in Iran and Turkey, as "visionary" leadership is found to be among highly effective and desired leadership attributes according the two papers on Iran (Dastmalchian, Javidan, \& Alam) and Turkey (Paşa, Kabasakal, \& Bodur) in this issue.

Previous leadership studies investigated the universal and culture-specific dimensions of leader characteristics in various countries. These studies found support for both culture-specific (Bass, Burger, Doctor, \& Barrett, 1979; Gerstner \& Day, 1994; Rodriguez, 1990; Schmidt \& Yeh, 1992; Shackleton \& Ali, 1990; Smith \& Peterson, 1994; Smith, Missumi, Tayeb, Peterson, \& Bond, 1989) and universalistic views (Bass \& Avolio, 1993; Dorfman \& Ronen, 1991). Other researchers have argued that both culturespecific and universal views have validity (Bass, 1990; Dorfman, Howell, Hibino, Lee, Tate, \& Bautista, 1997; Den Hartog, House, Hanges, RuizQuintanilla, \& Dorfman, 1999; House, Wright, \& Aditya, 1997). Parallel with the third view, Dastmalchian, Javidan, and Alam in their paper in this issue discuss that they observed both etic and emic leadership attributes in Iran. Similar to Iran, respondents in Kuwait, Turkey, and Qatar perceived universal leader attributes like supportive, visionary, and charismatic as part of their outstanding leader profiles. On the other hand, respondents mentioned some emic leadership attributes, like familial, humble, and faithful in Iran, traditional-tribalistic in Qatar, and paternalistic in the Turkish case. Thus, effective leader attributes in the Middle Eastern societies carry many universalistic characteristics as well as some unique culture-specific attributes.

Among the culture-specific leader attributes, "consultation" or "participation" have a different meaning in this part of the world compared to Western societies and academic teachings. In the qualitative data collected from Kuwait, Turkey, and Qatar, respondents mentioned the importance of consultation and participation as contributing to outstanding leadership. Paşa, Kabasakal, and Bodur found that outstanding leaders in Turkey use participation to basically induce feelings of belonging to the group rather than to get consensus or improve decision quality. Similarly, Abdalla and Al-Homoud argue that in the Arab world the purpose of consultation is to satisfy the egos of the parties involved rather than to improve the quality of the decision. They further argue that the traditional work environment in Arab countries would improve if the leaders would use a consultative

(C) International Association for Applied Psychology, 2001. 
leadership style according to the spirit of Islam. "The concept of consultation, a counterpoise of autocratic rule, has a special value in the Islamic tribal societies as it is strongly recommended by the Koran and emphasised by Bedouin traditions." Parallel with this argument, Özen (1998) found that consultation emerges as a dominant leader attribute in a Turkish organisation that is known for carrying Islamic values.

Managing the dualities between the culture-specific values and the requirements of change is a difficult process and requires "extra-ordinary" characters or "heroes". In the four nations included in this forum, respondents described and actually labelled outstanding or effective leaders as carrying "super-human" characteristics. While the dominant values in society and organisations influence implicit leadership theories (House, Hanges, Ruiz-Quintanilla, Dorfman, Javidan, Dickson, \& Gupta, 1999), outstanding leaders have some universalistic attributes and they are extraordinary characters that are able to manage the dualities between tradition and change.

The findings of this research forum have important implications for both practicing managers in organisations dealing with international and crossnational business and academics who are developing theories. There are major similarities in the societal and organisational cultures of Iran, Kuwait, Turkey, and Qatar. Some of the similarities can be explained by the common Islamic religion that the populations of these four nations share. On the other hand, differences in language, ethnic background, and economic and social institutions would account for the differences in their cultures and implicit leadership theories. The necessities of the task and the profile of the task force would explain the differences between societal and organisational cultures. It has been shown in a study of pacific rim countries that such differences between societal and organisational cultures indeed exist and that they have a considerable influence on organisational design, flexibility, and human resource practices (Dastmalchian \& Blyton, 1998). It has also been shown that industry culture may in fact have a stronger influence on expected behaviours and norms of leaders that may override the influence of organisational cultures (Dastmalchian, Lee, \& Ng, 2000). While the societies in this part of the world have practices that do not engage in future-oriented behaviours such as planning and investing in the future, organisations have more future-oriented practices. In line with their organisational cultures, implicit leadership theories in these societies involve more performance and future orientation as well as other universalistic attributes such as charisma and supportive behaviour. Organisational leaders are expected to be sensitive to local cultures and traditions yet at the same time become initiators of change. Training programmes for managers in all types of organisations and academic theories would require such sensivity to both emic and epic dimensions, and would increasingly need to involve a combination of

(C) International Association for Applied Psychology, 2001. 
universalistic dimensions with culture-specific manifestations of these attributes and local traditions.

\section{REFERENCES}

Bass, B.M. (1990). Bass and Stodgill's handbook of leadership: Theory, research and managerial applications (3rd Edition). New York: Free Press.

Bass, B.M., \& Avolio, B.J. (1993). Transformational leadership: A response to critiques. In M.M. Chemers and R. Ayman (Eds.) Leadership theory and research (pp. 49-80). San Diego, CA: Academic Press.

Bass, B.M., Burger, P.C., Doctor, R., \& Barrett, G.V. (1979). Assessment of managers: An international comparison. New York: Free Press.

Dastmalchian, A., Lee, S., \& Ng, I. (2000). The interplay between organizational and national cultures: A study of Canada and South Korea. International Journal of Human Resource Management, 11(2), 388-412.

Dastmalchian, A., \& Blyton, P. (Eds.) (1998). Organizational flexibility in crossnational perspective. Special Issue, International Journal of Human Resource Management, 9(3), 437-515.

Den Hartog, N.D., House, R.J., Hanges, P.J., Ruiz-Quintanilla, S.A., \& Dorfman, P.W. (1999). Culture specific and cross culturally generalizable implicit leadership theories: Are attributes of charismatic/transformational leadership universally endorsed? Leadership Quarterly, 10(2), 219-256.

Dorfman, P.W., Howell, J.P., Hibino, S., Lee, J.K., Tate, U., \& Bautista, A. (1997). Leadership in western and Asian countries: Commonalties and differences in effective leadership processes across cultures. Leadership Quarterly, 8(3), 233-274.

Dorfman, P.W., \& Ronen, S. (1991). The universality of leadership theories: Challenges and paradoxes. Paper presented at the National Academy of Management annual meeting, Miami, FL.

Gerstner, C.R., \& Day, D.V. (1994). Cross-cultural comparison of leadership prototypes. Leadership Quarterly, 5(2), 121-134.

Hofstede, G. (1980). Culture's consequences: International differences in work related values. Thousand Oaks, CA: Sage.

Hofstede, G. (1983). The cultural relativity of organizational practices and theories. Journal of International Business Studies, 14(2), 75-89.

House, R., Hanges, P.J., Ruiz-Quintanilla, S.A., Dorfman, P.W., Javidan, M., Dickson, M., \& Gupta, V. (1999). Cultural influences on leadership and organizations: Project GLOBE. In W.H. Mobley (Ed.), Advances in global leadership, Vol. 1, pp. 171-233. Stanford, CN: Jai Press.

House, R., Wright, N.S., \& Aditya, R.N. (1997). Cross-cultural research on organizational leadership. A critical analysis and a proposed theory. In P.C. Early \& M. Erez (Eds.), New perspectives on international industrial/organizational psychology. San Francisco, CA: The Lexington Press.

Ilmihal (1999). Divantas Publications. Istanbul: Medya Ofset.

Kabasakal, H., \& Bodur, M. (1998). Leadership, values and institutions: The case of Turkey. Research Papers. Boğaziçi University, Istanbul, Turkey.

Özen, R. (1998). Mentoring, gender, and ideological perspectives: A case study. Doctoral dissertation, Boğaziçi University, Istanbul, Turkey.

(C) International Association for Applied Psychology, 2001. 
Rodrigues, C.A. (1990). The situation and national culture as contingencies for leadership behaviour: Two conceptual models. In S.B. Prasad (Ed.), Advances in international comparative management: A research annual (Vol. 5, 51-68). Greenwich, CT: JAI Press.

Ronen, S., \& Shenkar, O. (1985). Clustering countries on attitudinal dimensions: A review and synthesis. Academy of Management Review, 10(3), 435-454.

Schmidt, S.M., \& Yeh, R.H. (1992). The structure of leader influence: A crossnational comparison. Journal of Cross-Cultural Psychology, 23(2), 251-262.

Shackleton, V.-J., \& Ali, A.-H. (1990). Work-related values of managers: A test of the Hofstede model. Journal of Cross-Cultural Psychology, 21(1), 109-118.

Smith, P.B., \& Peterson, M.F. (1994). Leadership as event management: A crosscultural survey based on managers from 25 nations. Paper presented at the meeting of the International Congress of Psychology, Madrid.

Smith, P.B., Missumi, J., Tayeb, M., Peterson, M.F., \& Bond, M.H. (1989). On the generality of leadership styles across cultures. Journal of Occupational Psychology, 62, 97-109.

(C) International Association for Applied Psychology, 2001. 
Copyright of Applied Psychology: An International Review is the property of Blackwell Publishing Limited and its content may not be copied or emailed to multiple sites or posted to a listserv without the copyright holder's express written permission. However, users may print, download, or email articles for individual use. 